\title{
Native People and the Environmental Regime in the James Bay and Northern Quebec Agreement
}

\author{
EVELYN J. PETERS ${ }^{1}$
}

\author{
(Received 13 October 1998; accepted in revised form 1 June 1999)
}

\begin{abstract}
A major objective of the Cree and Inuit in signing the 1975 James Bay and Northern Quebec Agreement was to protect the environment and thus secure their way of life based on harvesting activities. The main elements of the federal, provincial, and Agreement environmental protection regimes are compared with respect to principles derived from the growing literature on indigenous peoples and environmental assessment. The Agreement contained pioneering provisions for environmental assessment; yet those provisions have not met many of the expectations of the Native people. Part of the dissatisfaction derives from the Agreement itself: some sections are vague and difficult to translate into practices; the advisory committee structures are not well suited to Native cultures; and the right to develop is woven throughout the sections on environmental protection. However, failures and delays in implementing the Agreement have also contributed to this dissatisfaction. These issues have implications for the negotiation strategies of other groups.
\end{abstract}

Key words: environmental assessment, James Bay and Northern Quebec Agreement, land-claim agreements, subsistence economies

RÉSUMÉ. Un objectif majeur des Cris et des Inuit en signant la Convention de la Baie James et du Nord québécois était de protéger l'environnement et de conserver ainsi leur mode de vie fondé sur les activités d'exploitation des ressources fauniques. On compare les principaux éléments contenus dans les régimes de protection environnementale fédéral, provincial et de la Convention avec les principes tirés de la documentation de plus en plus abondante sur les peuples autochtones et l'évaluation environnementale. La Convention contenait des clauses innovatrices concernant l'évaluation environnementale, mais ces clauses n'ont pas permis de répondre aux attentes des Autochtones. Cette insatisfaction tient en partie à la Convention même: certains articles sont vagues et difficiles à appliquer concrètement; les structures des comités consultatifs ne conviennent pas bien aux cultures autochtones; et le droit à la mise en valeur se faufile dans tous les articles traitant de la protection environnementale. Cependant, des échecs et des retards dans la mise en oeuvre de la Convention ont également contribué à cette insatisfaction. Ces questions ont des implications pour les stratégies de négociation d'autres groupes.

Mots clés: évaluation environnementale, Convention de la Baie James et du Nord québécois, accords sur les revendications territoriales, économies de subsistance

Traduit pour la revue Arctic par Nésida Loyer.

\section{INTRODUCTION}

Despite assumptions about their inevitable passing, indigenous hunting, fishing and trapping economies have survived in many areas of the North American continent. The flexibility of indigenous economies has enabled them to avoid or accommodate frontier activity and intrusion by withdrawing to more and more marginal lands (Brody, 1983; Kayahna Area Tribal Council, 1985). However, there are limits beyond which hunting economies and frontier development become irreconcilable. Introducing a collection of articles on the geography of indigenous struggles, Stea and Wisner (1984:5) described the most recent phase in a history of encroachment on indigenous peoples' land:

Having spent the better part of one hundred years pacifying their indigenous peoples and allocating to them what was then perceived as the very worst land...the major industrial powers are suddenly finding that these areas...cover enormous energy and mineral resources. Thus the dominant industrialists buttress these nation-states' own attempts [to incorporate marginal lands] with notions of "energy crisis" and "strategic minerals." Oil, coal, and uranium are the chief foci, although in some places surface and even underground water has begun to be re-evaluated by capital as potentially strategic.

This phase may result in the destruction of those indigenous hunting economies that have survived.

Maintaining a subsistence economy is seen as a decisive factor in indigenous peoples' struggles for cultural survival (Berger, 1985; Jull, 1988; Simon, 1992; Brascoupé, 1993; Nuttall, 1994). Indigenous peoples internationally have used a variety of strategies to combat the threat that

${ }^{1}$ Department of Geography, Queen's University, Kingston, Ontario K7L 3N6, Canada; peterse@ post.queensu.ca

(C) The Arctic Institute of North America 
uncontrolled economic development poses for their economies and ways of life (Stea and Wisner, 1984; Burger, 1987). In Canada, the possibility of enhancing their ability to maintain a subsistence economy has been a major impetus for indigenous peoples' attempts to assert sovereignty over their lands and their lives through land-claim negotiations and self-government arrangements (Peters, 1989). While some arrangements have existed for more than two decades, there is almost no work that evaluates their appropriateness in protecting environments for the subsistence use of indigenous peoples (Young, 1995 is an exception).

In Canada, the James Bay and Northern Quebec Agreement (hereafter, the Agreement) was signed in 1975. While the Agreement was the product of an out-of-court settlement rather than a land-claim settlement, it became an important precedent in subsequent land-claim negotiations. A major Cree and Inuit objective in negotiating the Agreement was to secure their way of life based on harvesting activities (Feit, 1980, 1988; Brooke, 1995). The process of implementing the Agreement has helped to define its status in Canadian law. This experience may be of interest to other indigenous groups attempting to design mechanisms for protecting their lands and economies.

After a brief background to the negotiation of the Agreement and to Cree and Inuit objectives with respect to environmental protection, this paper outlines the main elements of the environmental protection regimes for Cree and Inuit lands under the Agreement. The Cree protest against the Great Whale hydroelectric project is described to illustrate some issues involved in implementing provisions of the Agreement. While the Inuit did not oppose the project in the same way, the Cree experience provides an important context for the analysis. The final section evaluates the environmental protection regime in the Agreement and the appropriateness of Agreement, federal, and provincial regimes for protecting indigenous economies, using principles derived from the growing literature on environmental assessment and indigenous peoples. The paper relies mainly on materials produced by the Cree and Inuit and individuals working for their organizations: as the question here is whether provisions in the Agreement meet the needs of the indigenous residents, their views count the most.

\section{NEGOTIATING THE AGREEMENT}

In 1971, the Quebec government began to construct the James Bay Hydroelectric Project in an area not yet ceded by the Native peoples, and which was still used by them in their traditional hunting pursuits (Richardson, 1975; LaRusic, 1979; Salisbury, 1986). The land in question had been transferred by the federal government to Quebec under the 1912 Boundary Extension Act, with the condition that the province obtain surrender of Native interests in the area prior to development. When the province failed to negotiate, the Cree and Inuit instituted legal proceedings against Quebec and the James Bay Development Corporation in May 1972.

Mr. Justice Malouf of the Quebec Superior Court granted the Cree and Inuit a hearing and, after receiving the testimony of Inuit and Cree hunters about their continuing use and occupation of these lands, accorded an interlocutory injunction against the hydroelectric development in process. The Malouf decision was suspended a week later pending a final decision by the Quebec Court of Appeal on a permanent injunction. Quebec's fear that in the end the Cree might be awarded substantial damages and the inability of the Cree and Inuit to stop construction during court proceedings provided the impetus for both sides to negotiate an out-of-court settlement. An agreement-in-principle was reached on 15 November 1974. On 21 November 1974, the Quebec Court of Appeal denied the Cree and Inuit a permanent injunction, putting an end to litigation on that issue. A final agreement was completed in November 1975.

Quebec's intention in negotiating the Agreement was to affirm its presence and jurisdiction over the territory and to open the area for economic development (Ciaccia, 1976:xixxiv). Hydroelectric development of Quebec's northern rivers was a long-standing objective of Robert Bourassa, Quebec's Premier during many of the events described here (Bourassa, 1985). In an attempt to prevent aboriginal people from blocking regional development, Quebec insisted that the province retain final control over authorization of economic development in the territory referred to in the Agreement, except on lands reserved for aboriginal communities.

Unable, in the face of Quebec's objectives, to gain jurisdiction over the whole territory, Cree and Inuit negotiators followed a number of strategies to protect the land for subsistence activities. They negotiated a detailed hunting regime that allowed them continuing access to wildlife resources on most of the lands of the territory referred to in the Agreement (Section 24), and they obtained financial support programs for Cree and Inuit harvesters (Sections 29 and 30). The focus of this paper, however, is on Sections 22 and 23 in the Agreement, which attempt to protect the environment for harvesting activities.

When the Agreement was negotiated, there were few precedents or models for environmental protection. Where they existed at all, federal and provincial environmental and social protection regimes were weak, with no explicit social component, limited provisions for public involvement, and no general obligation to conduct impact assessments and reviews. Yergeau (1988:296) reviewed the environmental regime in the Agreement a decade after it was signed:

The Agreement is a pioneering document in the field of environmental protection, in particular with respect to the criteria governing environmental and social impact statements....[T] hat it stated all this in 1975 was evidence of an unheard-of boldness far in advance of any other legislation in the world dealing with the environmental impacts of development. 
In 1980, Feit (1980:12) demonstrated a cautious optimism about the effectiveness of the environmental regime outlined in the Agreement.

The combination of these distinctive principles, obligatory consultations, special representations and mechanisms for inputs into consultations, was thought to sufficiently constrain the exercise of governmental authority that it would have to respect and, in part, serve Cree interests and concerns. The compromises involved in accepting this more limited control over development activities and social and environmental protection were hard ones for the Cree, and it is still too soon to tell whether or not these provisions will be adequate.

Within a decade, Feit's evaluation had changed.

The threat to the hunting economy posed by relatively unregulated industrial development of the region pinpoints the...failure of the agreement process to effectively resolve conflicts over resource control and economic development. Large-scale industrial development projects are continuing on Cree lands.... [T] he failure to adequately regulate development is a major future threat to the revitalized hunting sector. These threats demonstrate...that the agreement process was unable to resolve fundamental conflicts between the interests of Cree and those of wider economic and political institutions of the capitalist economy or the liberal democratic state. (1989:96-97)

Nevertheless, the sections of the Agreement referring to environmental protection played a major role in the Cree protest against the Great Whale River hydroelectric project, which was put on hold in 1994. Moreover, the federal and provincial governments and the Cree and Inuit have been negotiating implementation issues for more than two decades (Peters, 1989; Brooke, 1995; Penn, 1995). Thus it is difficult to know whether the problem lies with specific provisions of the Agreement, or with the ways in which those provisions have (or have not) been put into effect. The following paragraphs attempt to evaluate these issues.

\section{MAIN COMPONENTS OF THE SOCIAL AND ENVIRONMENTAL PROTECTION REGIME}

\section{Land Regime}

The Agreement distinguishes three main classes of land (Categories I-III) with respect to allocation of title, resources, interest, and jurisdiction. Provincial insistence on opening up the area for economic development limited the size of the land base over which the Cree and Inuit could negotiate ownership or control.

Category I lands correspond to the locations of Cree and Inuit villages and their peripheries (Figs. 1 and 2). Category IA lands are areas transferred by Quebec to Canada for the exclusive use and benefit of the Cree bands. Category IB lands are areas whose ownership has been transferred by Quebec to Cree landholding corporations. In the case of the Inuit, Category I lands are areas whose ownership Quebec has transferred to Inuit Village Corporations. Category I lands are sufficient in size for community sites with some buffer between the community and adjacent development. However, such areas provide only very limited protection for the hunting economy. Moreover, Category I lands are subject to fairly extensive expropriation powers of the federal and provincial governments.

Category II lands adjoin Category I lands. They are lands under provincial jurisdiction on which the Cree and Inuit have exclusive rights of harvesting and outfitting. Category II lands may also be expropriated by Canada or Quebec for development.

Category III lands cover the balance of the territory referred to in the Agreement. Native people have exclusive rights to trap and create commercial fisheries for some species on Category III lands. These lands are areas of joint use by Native and non-Native peoples, but Native people are to be subject to a minimum of control or regulation with respect to hunting and fishing, and any controls imposed on them must be decided by a Hunting, Fishing, and Trapping Coordinating Committee on which Native people are represented. (The harvesting regime for the Agreement is found in Section 24 of the Agreement. A full description of this regime is beyond the scope of this paper, but see Brooke, 1995.) While the Cree and Inuit have little power to restrict non-renewable resource or economic development on Category II and III lands, and while the Agreement explicitly gives Quebec the right to economic development on these lands, Quebec's rights are subject to the environmental regimes set out in the Agreement.

\section{Environmental Protection Regimes}

Sections 22 and 23 of the Agreement set out the processes and criteria to be employed in assessing the social and environmental effects of developments south and north of the 55th parallel, respectively. The Great Whale River hydroelectric development, described in the following section, would have been located in both areas.

The James Bay Advisory Committee on the Environment (JBACE) and the Kativik Environmental Advisory Committee (KEAC) were created to facilitate Cree and Inuit input into all aspects of decision making about the management of development in the area referred to in the Agreement (Table 1). These committees were established as consultative bodies to responsible governments on issues concerning the environmental regime and the formulation of laws relating to the environment. Their responsibility is to review existing and proposed development-related legislation and regulations (including environmental impact assessments) that affect Cree and Inuit environments and recommend environmental 


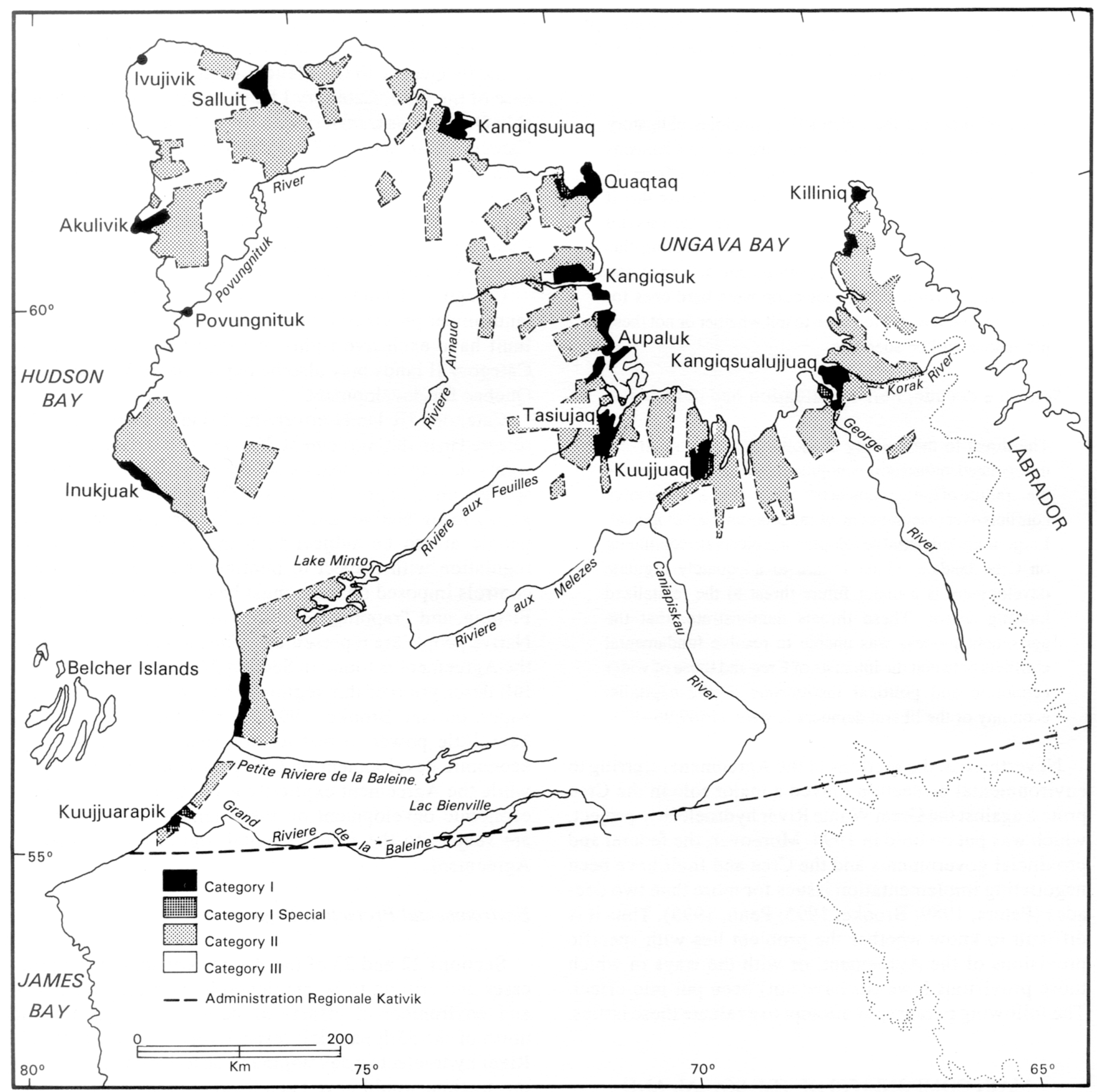

FIG. 1. Inuit land selection, 1975.

laws, regulations, and other measures to responsible governments. Federal and provincial governments are required to fund a secretariat for the committees, and the committees can call on expert advice if necessary.

The bodies formed to deal specifically with impact assessment processes are also described in Table 1. Federal and provincial governments fund staffing requirements for these bodies and pay for experts required in their deliberations. When a new development is proposed, the review bodies make recommendations to the appropriate
Administrator about the need for an environmental impact statement and and its nature and extent. The Administrator makes the decision and, if appropriate, issues guidelines for the assessment to the proponent. There is no provision for public consultation at this stage. The review bodies evaluate the environmental impact statement submitted by the proponent and, except for the Kativik Environmental Quality Commission (KEQC), recommend to the Administrator under what conditions a development may proceed. The KEQC can decide whether or not a development 


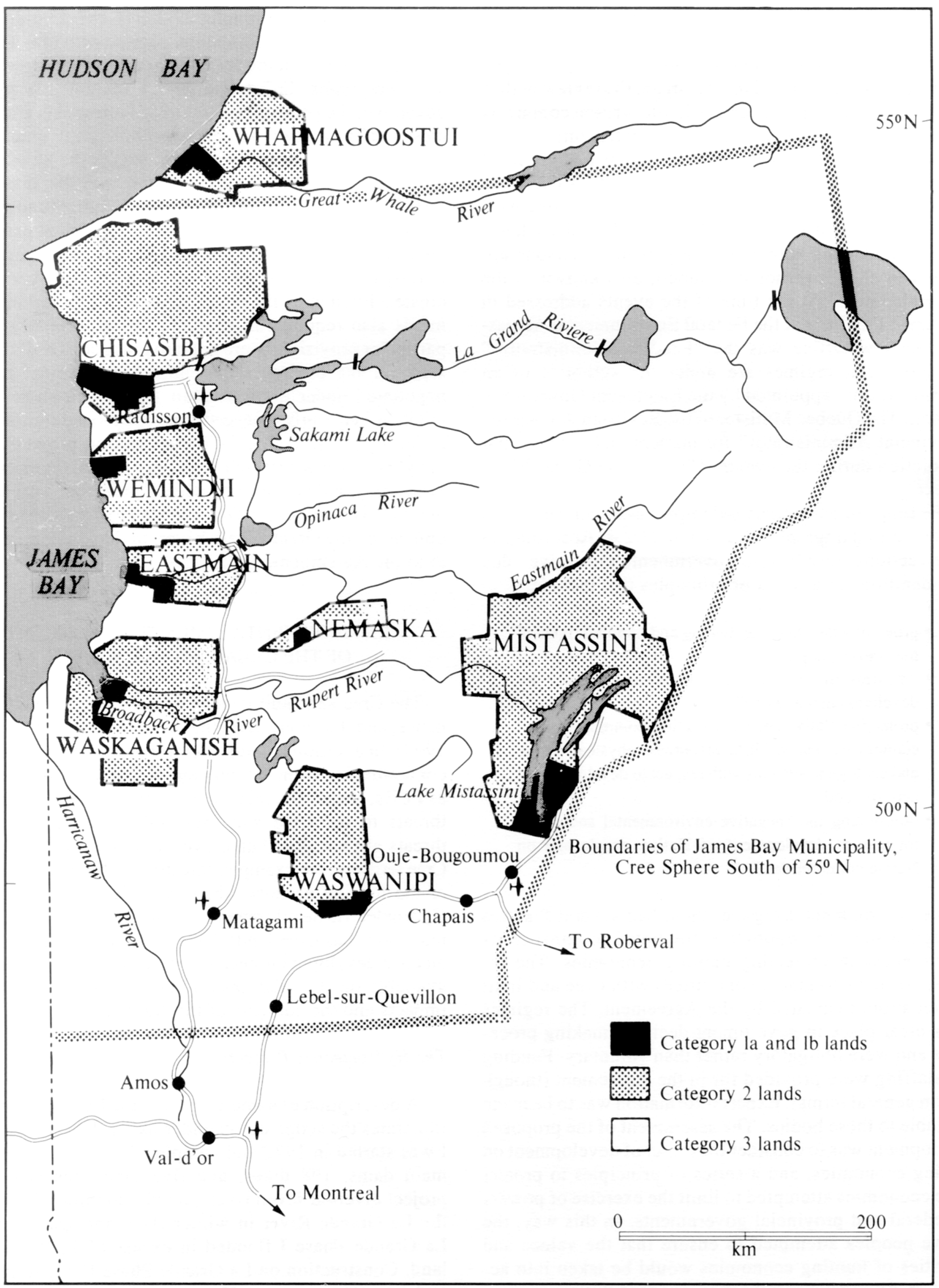

FIG. 2. Cree land selection, 1975. 
may proceed, and the Quebec Administrator must obtain the approval of the Lieutenant Governor in Council if he or she does not wish to follow the decision of the KEQC. During the evaluation and review stage, the review bodies may hold public consultations or invite written comments concerning the environmental impact statement.

The Agreement indicates that a Cree or Kativik local government "Administrator" is responsible for decisions about matters affecting the environment on Category I lands. The federal regime on Category II and III lands operates under the authority of a person or persons appointed by the Governor in Council, also known as the "Administrator." At the time of the events addressed in this paper, the Chair of the Federal Environmental Assessment Review Office was the "Federal Administrator." The provincial regimes are under the authority of an "Administrator" appointed by the Lieutenant Governor in Council. The Quebec Minister of the Environment was the "Provincial Administrator" for matters under provincial jurisdiction during the events related to the Great Whale project.

The scope of environmental impact assessments is also addressed in paragraphs 22.2.4 and 23.2.4. According to these sections, responsible governments must give "due consideration" to a series of principles that include:

\footnotetext{
- protecting the "hunting, fishing and trapping rights of the Native people";

- "minimizing the impact on Native people by developmental activity";

- protecting Native people, societies, communities and economies, and wildlife resources, physical, biotic and ecological systems with respect to developmental activity; and

- minimizing the "negative environmental and social impacts of development on Native people and on Native communities."
}

The environmental regime, then, had several features through which the negotiators attempted to enhance its effectiveness in protecting hunting economies. The regimes created permanent committees with Cree and Inuit participation, mandated by the Agreement. The regimes had a clear place in government decision-making procedures and were obligatory rather than voluntary. Funding and staffing were provided for in the Agreement (though only in general terms). Expert information was to be made available to these bodies. The assessment of the proposed development was to consider the effect of development on hunting economies, and a series of principles to protect these economies attempted to limit the exercise of powers by federal and provincial governments. In this way, the Native peoples attempted to ensure that the values and priorities of hunting economies would be taken into account in development activities and that these activities would address the potentially negative effects on Native communities and cultures.
However sub-paragraphs 22.2.2(f) and 23.2.2(f) also indicate that the environmental regime provides for "the right to develop" in the area referred to in the Agreement, and paragraphs 22.2.4 and 23.2.4 include the right to develop in the principles to which governments and agencies "shall give due consideration." Moreover, clauses and arrangements in the Agreement do not tell the whole story. The meaning of particular phrases may be contested, implementation may be slow or partial, federal and provincial governments may choose not to implement particular elements, and Native peoples may not have the resources to fully participate in the bureaucracy that the Agreement created. Evaluating the effectiveness of particular arrangements also requires an examination of instances where particular provisions were put into practice. Reed's (1990) study of the environmental impact assessment process negotiated under the Inuvialuit Agreement showed that practice frequently diverged from the procedures outlined in the Agreement. The following section provides some insights into how parts of the environmental regimes in the James Bay and Northern Quebec Agreement were implemented. The context is the proposed hydroelectric development on the Great Whale River, in the territory referred to in the Agreement.

\section{ENVIRONMENTAL IMPACT ASSESSMENT OF THE GREAT WHALE PROJECT}

The Cree and Inuit depend on the land for their sustenance, and they consider it their own (Brooke, 1995; Penn, 1995). In addition to hydroelectric development, forestry, contamination from mercury and airborne substances such as PCBs, roads, and mining development represent major threats to the Cree and Inuit subsistence base. These threats are not distributed evenly. In the southern part of Cree territory, for example, forestry is taking more land out of the hunting economy than hydroelectric development. Hydroelectric development has not affected Inuit lands as much as it has Cree lands. This section focuses on hydroelectric development because more published material is available on the relationship between its environmental impacts and the contents of the Agreement.

\section{The Hydroelectric Projects}

A description of some aspects of the La Grande project illustrates the scope of the undertaking. La Grande Phase I was started in 1973 and completed in 1986. With eight main dams, 198 dikes, and five major reservoirs, the project diverted seven rivers, nearly doubling the flow of the La Grande River in winter (Day and Quinn, 1992). La Grande Phase I flooded in excess of $10000 \mathrm{~km}^{2}$ of land. Construction on La Grande Phase II began in 1991 and is now complete. This phase involved constructing one reservoir, diverting one river, and flooding an area of $765 \mathrm{~km}^{2}$. 
TABLE 1. Environmental protection bodies under the Agreement.

\begin{tabular}{|c|c|c|}
\hline Committee & Membership & Section \\
\hline \multicolumn{3}{|c|}{ Reviewing and Formulating Laws and Regulations for Environmental Protection } \\
\hline $\begin{array}{l}\text { South of the 55th Parallel } \\
\text { James Bay Advisory Committee on the Environment (JBACE) }\end{array}$ & $\begin{array}{l}\text { Four representatives appointed by each of the Cree Regional Authority (CRA), } \\
\text { Quebec, Canada, plus the Chair of the Hunting, Fishing and Trapping } \\
\text { Coordinating Committee }\end{array}$ & 22.3 \\
\hline $\begin{array}{l}\text { North of the 55th Parallel } \\
\text { Kativik Environmental Advisory Committee (KEAC) }\end{array}$ & $\begin{array}{l}\text { Three representatives appointed by each of the Kativik Regional Government } \\
\text { (KRG), Quebec, Canada }\end{array}$ & 23.5 \\
\hline \multicolumn{3}{|c|}{ Setting Guidelines for Environmental and Social Impact Assessment } \\
\hline $\begin{array}{l}\text { South of the 55th Parallel } \\
\text { Evaluating Committee (COMEV) }\end{array}$ & $\begin{array}{l}\text { Two representatives appointed by each of the Cree Regional Authority (CRA), } \\
\text { Quebec, Canada }\end{array}$ & 22.5 \\
\hline $\begin{array}{l}\text { North of the 55th Parallel } \\
\text { Kativik Environmental Quality Commission (KEQC) } \\
\text { Federal Review Committee North (FRC-North) }\end{array}$ & $\begin{array}{l}\text { Four representatives appointed by the KRG, five by Quebec } \\
\text { Two representatives appointed by the KRG, three representatives by Canada }\end{array}$ & $\begin{array}{l}23.3 \\
23.4\end{array}$ \\
\hline \multicolumn{3}{|l|}{ Evaluating and Reviewing Impact Assessments } \\
\hline $\begin{array}{l}\text { South of the 55th Parallel } \\
\text { Provincial Review Committee (COMEX) } \\
\text { Federal Review Committee (FRC-South) }\end{array}$ & $\begin{array}{l}\text { Two representatives appointed by the CRA, three by Quebec } \\
\text { Two representatives appointed by the CRA, three by Canada }\end{array}$ & $\begin{array}{l}22.6 \\
22.6\end{array}$ \\
\hline $\begin{array}{l}\text { North of the 55th Parallel } \\
\text { Kativik Environmental Quality Commission (KEQC) } \\
\text { Federal Review Committee North (FRC-North) }\end{array}$ & $\begin{array}{l}\text { Four representatives appointed by the KRG, five by Quebec } \\
\text { Two representatives appointed by the KRG, three representatives by Canada }\end{array}$ & $\begin{array}{l}23.3 \\
23.4\end{array}$ \\
\hline
\end{tabular}

In 1989, Quebec announced plans to begin a second hydroelectric development project on the Great Whale River. The proposed Great Whale River project, often called James Bay II, would have diverted water from four major rivers into the Great Whale River. The project entailed 4 reservoirs that together cover $4387 \mathrm{~km}^{2}, 5$ dams, 133 dikes, and 3 generating stations.

The Cree have argued that the ongoing and proposed hydroelectric projects and their short- and long-term social and environmental effects have had and will continue to have serious negative effects on their hunting economies and their society (Hodgins and Cannon, 1995). As a consequence, they took the lead in an ongoing legal and public relations battle to halt construction or, failing that, to ensure that developers minimized the damage to Cree lands.

\section{Environmental Impact Assessment of the Great Whale River Hydroelectric Project}

Quebec decided to reactivate work on the Great Whale River hydroelectric project (the project had been on the drawing board since 1975, but further work was postponed in 1982) without consulting any of the review bodies set up under the Agreement. Instead, the province indicated that an environmental impact assessment would be conducted under provincial guidelines. According to section 8.1.3, hydroelectric projects in the area referred to by the Agreement are exempt from social impact assessment and are "subject to the environmental regime only in respect to ecological impacts." The exemption, however, does not bypass other aspects of the environmental impact assessment process defined in the Agreement.
Ottawa's initial position was that because the project might affect areas under federal jurisdiction, an assessment was required under the Federal Environmental Assessment Review Process (EARP) and, in addition, that a federal review was required pursuant to sections 22 and 23 of the Agreement. Quebec argued that no federal review was required because the project was under provincial jurisdiction (Posluns, 1993).

In October 1990, Quebec proposed to split the environmental review of the Great Whale project into two stages. In the first stage, a commission would study the impact of access infrastructure, such as roads, airports, bridges, and docks. Quebec contended that Ottawa should not be involved in this phase because these were not matters under federal jurisdiction. The second stage would examine the impact of the dams, dikes, reservoirs, and powerhouses. Neither of these reviews was to be conducted pursuant to the Agreement. While the first phase of the provincial review was held up in the courts by legal challenges, Quebec began construction. A troubling implication of construction starts and of the split review was that, once millions of dollars worth of access infrastructure was in place, it would be politically difficult for the public review panel to deny the project, or even recommend substantial changes.

The following month, the federal government abruptly reversed its earlier position, informing the Cree that Ottawa had no mandate for a separate federal review of the Great Whale project. (See Posluns (1993) for a good overview of these events.) Instead, Ottawa and Quebec agreed to a single joint review; the federal portion would be submitted to the provincial review body. The federal review would follow the federal EARP guidelines rather than those of the James Bay and Northern Quebec Agreement. 
While the Inuit entered into negotiations with HydroQuebec concerning project impacts and mitigating measures, the Cree launched a motion in the Federal Court to try to force the federal government to live up to its responsibilities under the Agreement (Cree Regional Authority v. Robinson, [1991] 2 C.N.L.R. 41). The challenge for Cree lawyers was twofold. They had to demonstrate that the James Bay and Northern Quebec Agreement had the status of a federal law, and they had to prove that sections 22 and 23 applied to the Great Whale project. Justice Rouleau of the Federal Court, Trial Division ruled on the first question on 13 March 1991. He indicated that the Agreement did not have the status of a contract, as federal lawyers had argued: Parliament had intended it to operate as a law of Canada. He added:

I feel a profound sense of duty to respond favourably [to the Cree application]. Any contrary determination would once again provoke, within the native groups, a sense of victimization by white society and its institutions. This agreement was signed in good faith for the protection of the Cree and Inuit peoples, not to deprive them of their rights and territories without due consideration. (Cree Regional Authority v. Robinson [1991] 2 C.N.L.R. 41 at 48)

On 28 March 1991, the Federal Court of Appeal upheld this decision (Hydro-Quebec v. A.-G. Canada et al. [1991] 3 C.N.L.R. 41 at 82), and on 14 May 1991 the Supreme Court of Canada refused the Attorney General of Quebec and Hydro-Quebec's motion for leave to appeal.

In July 1991, Jean Charest, the new federal Minister of the Environment, announced that the federal government was legally bound to a separate review of the Great Whale Project because of its possible impact on areas under federal jurisdiction, for example fisheries, migratory birds, and navigation on harnessed rivers. He indicated, however, that the federal review would be under the federal Environmental Assessment Review Process (EARP). The federal government maintained that it could not prevent Quebec from beginning to build $\$ 775$ million worth of access infrastructure, including roads, marine terminals, and airports, during the estimated two years of hearings. Moreover the federal government argued that in cases of overlapping jurisdiction, it did not have the constitutional authority to block the project (Day and Quinn, 1992).

In September 1991, Justice Rouleau of the Federal Court, Trial Division ruled that the federal government had a public, nondiscretionary duty to carry out an independent federal review, pursuant to the terms of the Agreement. Justice Rouleau spelled out the nature of federal decision-making responsibilities:

Sections 22.5.15 and 23.4.9 of the JBNQ Agreement impose a mandatory duty on the federal administrator to decide whether or not an environmental and social impact assessment and review is required, and to determine the nature and extent of any such assessment and review.
Sections 22.6.15 and 23.4.23 assign to the federal administrator the obligation to either advise the developer respecting the alternative submitted or to decide, based on environmental and social impact considerations, whether or not a proposed development should proceed. (Cree Regional Authority v. Robinson [1991] 4 C.N.L.R. 84 at 85)

Justice Rouleau also pointed out that the federal government, if it did not already have a fiduciary responsibility toward the Cree, incurred that responsibility when it extinguished their Native rights pursuant to the Agreement.

On 23 January 1992, with a view to carrying out a global and coordinated assessment of the proposal, the federal and Quebec governments, the Cree Regional Authority, the Grand Council of the Crees (of Quebec), the Kativik Regional Government, and the Makivik Corporation signed a Memorandum of Understanding concerning the coordination of environmental assessment and review processes stemming from sections 22 and 23 of the James Bay Agreement with the federal EARP. The Great Whale Public Review Support Office, created by virtue of the Memorandum, had as its objective the harmonization and coordination of the work of the review bodies (Evaluating Committee et al., 1992).

Guidelines for the environmental impact assessment of the proposed Great Whale Hydroelectric Project were transmitted to Hydro-Quebec in September 1992. In August 1993, Hydro-Quebec submitted a feasibility study containing the environmental impact statement (EIS) associated with the Great Whale project.

In their evaluation of Hydro-Quebec's submission, the review bodies concluded that "As submitted by the Proponent, the EIS is presently neither sufficiently complete nor adequate for the decision-making process" (Provincial Review Committee et al., 1994:3):

In its introduction, the Joint Report highlighted seven major inadequacies, including:

- ambiguities related to study area boundaries and project schedule;

- treatment of principal assessment criteria...;

- knowledge of human societies affected;

- approach to the study of the combined and integrated effects of the proposed project;

- justification of the proposed project;

- appreciation of the uncertainty associated with the proposed project's impacts;

- selection of mitigation measures and the short- and long-term management of the proposed project.

(Provincial Review Committee et al., 1994:4)

A general discussion of the major shortcomings of the report was followed by more than 100 pages of detailed instructions for revisions.

The Joint Report was completed on 16 November 1994. The report was never officially released, but it was forwarded to Hydro-Quebec. On 18 November 1994, Quebec 
announced that the Great Whale project would be put on hold. Clearly this decision was not a response to the Joint Report. The Grand Council of the Crees, with other activists, had mounted an intensive and highly successful public relations campaign on the eastern seaboard of the United States. Moreover, the low price of natural gas in the United States at that time allowed for the low-cost production of electricity in local generators. These developments resulted in the cancellation of several contracts to purchase Hydro-Quebec electricity (Posluns, 1993; Grand Council, 1995:23). Because the Great Whale project was cancelled, some of the implications of the environmental regime in the Agreement were not fully worked out for this project. Nevertheless, the case demonstrates some of the issues that are important for an evaluation of the environmental regime.

\section{THE AGREEMENT AND FEDERAL AND PROVINCIAL ENVIRONMENTAL IMPACT ASSESSMENT REGIMES}

Table 2 compares three environmental regimes-the federal EARP and its successor, the 1992 Canadian Environmental Assessment Act; Quebec's environmental assessment regulations; and the environmental regime set out in sections 22 and 23 of the Agreement-with respect to processes in place for assessing impacts on and protecting subsistence economies. The Agreement supersedes provincial legislation with respect to environmental impact assessments. However, provincial legislation is described here for purposes of comparison. The assessment criteria used to compare federal, provincial, and Agreement provisions have emerged from a growing literature on Native peoples and environmental assessment. These criteria are discussed individually below.

\section{Mandatory Review and Assessment}

All three review processes are mandatory. At the beginning of the attempt to implement the environmental assessment process of the Agreement for the Great Whale River project, the federal EARP was viewed as discretionary. However, rulings from court cases concerning RaffertyAlameda Dam (Canadian Wildlife Federation Inc. v. Canada, 1989) and the Oldman River Dam (Friends of the Oldman River Society v. Canada 1992) indicated that the federal government had the mandatory duty to perform an environmental impact assessment of any project that involved aspects of federal jurisdiction. In 1992, the Canadian Environmental Assessment Act (CEAA) was put in place, in part to make these requirements clear. Quebec's Environment Quality Act (1972), amended in 1978, requires an environmental assessment of all projects identified by the regulations of that Act. The environmental regimes under the Agreement place a legal obligation upon all development proponents to comply with its provisions. The legal status of the regimes is based on the James Bay and Northern Quebec Final Agreement, 1975, and validated by the federal James Bay and Northern Quebec Native Claims Settlement Act, 1977 and Quebec's Act approving the Agreement concerning James Bay and Northern Quebec, 1976.

It is worth noting, though, that it took a court decision to force the federal government to live up to its responsibilities and to agree to an environmental assessment pursuant to the federal environmental regimes specified in the Agreement.

\section{Mandatory Assessment of Social Impacts}

Provincial, federal, and Agreement regimes vary with respect to the requirement for social impact assessment. Social impacts are not a necessary part of the provincial evaluation procedure. In the 1984 Order-in-Council, the scope of the EARP was defined to include assessment of socioeconomic impacts that resulted directly from changes in the biophysical environment. The Guide published by the Federal Environmental Assessment Review Office (FEARO) in 1986 notes:

\begin{abstract}
Although the initiating department will determine the extent to which socio-economic impacts are to be taken into account in initial assessment, as a minimum, the potential social change associated with the biophysical impacts of a proposal must be considered. (Canada, Federal Environmental Assessment Review Office, 1986:26)
\end{abstract}

The 1992 Canadian Environmental Assessment Act requires the examination of "environmental effects" that include:

any effect of any such change on health and socioeconomic conditions, on physical and cultural heritage, on the current use of lands and resources for traditional purposes by aboriginal persons or on any structure, site or thing that is of historical, archaeological, paleontological or architectural significance. (s. 2[1])

Under the Agreement, while hydroelectric development is exempt from social impact assessment, other economic development is not. Sections 22 and 23 of the Agreement are explicit with respect to the requirement for a social impact assessment. The assessment is described as an environmental and social impact assessment throughout these sections, and Schedule 3 of each section, which describes the contents of the impact statement, includes the specification of social impacts. However, a requirement to evaluate social impacts does not guarantee that the resultant decision making will take them into account. The Cree experience has been that the Quebec Ministry of the Environment took the position that it was empowered to make decisions only in areas where it had statutory or regulatory authority to do so. Decisions concerning social, economic, or cultural issues could not be imposed on other 
TABLE 2. Environmental impact assessment under federal, Quebec and Agreement processes.

\begin{tabular}{|c|c|c|c|}
\hline & Federal EARP & Quebec Legislation & James Bay Agreement \\
\hline Mandatory review and assessment & Yes & Yes & Yes \\
\hline Mandatory assessment of social impacts & Yes & No & Yes \\
\hline Mandatory consideration of measures to protect hunting economies & No & No & Yes \\
\hline Cree and Inuit jurisdiction over development decisions & No & No & See note ${ }^{1}$ \\
\hline Incorporation of Cree and Inuit values in impact assessment & No & No & No \\
\hline \multicolumn{4}{|l|}{ Incorporation of Cree and Inuit values in decision-making processes } \\
\hline - participation on review bodies & No & No & Yes \\
\hline - culturally appropriate decision-making processes & No & No & No \\
\hline Incorporation of Cree and Inuit values in defining desirable futures & No & No & Yes \\
\hline
\end{tabular}

${ }^{1}$ Limited - Cat. I land; Advisory - Cat. II and Cat. III land

departments that did not participate in or have input into the assessment procedure (Penn, 1995). Despite the clear requirement for social impact assessment, then, its implementation has proved elusive.

\section{Mandatory Consideration of Measures to Protect Hunting Economies}

The definition and measurement of social impacts is a value-laden exercise, and standard approaches may not provide techniques or concepts that are effective in protecting subsistence economies. Researchers have argued that it is particularly difficult to construct appropriate methodological frameworks and processes for aboriginal peoples (Shapcott, 1989; Ross, 1990; Notzke, 1994).

The assessment of social impacts for northern aboriginal communities requires a different paradigm than that required for non-aboriginal communities (Elias and Weinstein, 1992, Vol. 1:5f; Weinstein et al., 1992:8f). For example, many of the activities that comprise subsistence economies do not have an easily calculated market value; as a result, benefits from the introduction of a wage economy can easily be overvalued. More importantly, a model that views the replacement of a hunting, fishing, trapping, and gathering society with one based on wagelabour and business as a simple substitute of one kind of economy for another does not provide an adequate conceptualization of the meaning of the land-based activities that make up subsistence economies. Notzke (1994:277) argues that:

The past two decades have shown that the effects of industrial resource developments on small, northern aboriginal communities are fundamentally different from those on non-aboriginal communities. Studies conducted in various communities...show the enduring importance of wildlife, fish and plant resources in the livelihood of native people. The reason for this is that renewable resources do not merely constitute the economic base for aboriginal communities, but their harvesting provides the major integrative social force [emphasis in original].
The loss of harvesting opportunities represents more than the loss of an income-generating activity for which a substitute can be found through wage-labour or social assistance.

Because there is no requirement in Quebec legislation for a social impact assessment, an evaluation of impacts on hunting economies is not required either. Social impact assessment was part of the federal environmental assessment review process, and it is part of the current Canadian Environmental Assessment Act; however, its presence does not guarantee the appropriate assessment of impacts on subsistence economies, for the reasons outlined above. The Canadian Environmental Assessment Research Council's research prospectus (1985) identifies the types of social change usually investigated as part of a social impact assessment as demographic, economic, resourcerelated, and cultural. This provides a good summary of other approaches (see also Barrow, 1997:234) and demonstrates some of the limitations of current social impact assessment practices for dealing with subsistence economies. Clearly, changes in hunting economies cut across all of these categories, and there is little provision for an analysis that recognizes their interrelatedness. Moreover, economic changes are conceptualized primarily in terms of income-generating activities, with the result that many subsistence activities are marginalized.

The Agreement potentially provides more scope for directing attention to the particular nature of subsistence economies. As noted above, Sections 22 and 23 introduce a series of guiding principles designed to protect Native economies. In addition, paragraphs 22.2.2 and 23.2.2 describe the environmental protection regime as one that provides for the "protection of the Cree/Inuit people, their economies and the wildlife resources upon which they depend." Schedule 3 of both sections states that "the impact assessment procedure should contribute to a further understanding of the interactions between Native people, the harvesting of wild life resources and the economic development of the Territory" (Canada, Quebec, 1976: 332, 357). The list of social conditions that form part of the impact assessment specifically includes "harvesting patterns" and the use and importance of various species in harvesting activities. 
However these principles and clauses do not provide detailed methods for assessing the effects on hunting economies. In a 1985 review of the Agreement, Penn (1988:130) noted that:

[I]t has proved difficult to translate such general principles into operational language. However simple and straightforward the principles may sound, we are still some way from understanding how to translate them into the detailed and subject-specific language of impact assessment or environmental policy. However, the concept of the guiding principle is sufficiently important in the Agreement that operational definitions of these principles will have to be found.

Nevertheless, sections 22 and 23 of the Agreement do insist that hunting economies be taken seriously in the evaluation of impacts of development. In this way they provide some scope for constructing an appropriate approach to subsistence economies in the assessment of development in the territory referred to in the Agreement.

\section{Cree and Inuit Jurisdiction over Development Decisions}

Neither federal nor provincial impact assessment procedures provide Native peoples with jurisdiction over industrial development. Under the federal EARP and the CEAA, the Minister of the Environment or the initiating Minister (the minister responsible for the agency proposing to undertake or authorize the project) makes decisions about whether or not the development should take place and under what terms and conditions. Under provincial legislation, authority for decision making about development projects is given to the Lieutenant-Governor in Council, or delegated to a committee of ministers.

The Agreement allows the Native people limited control over development in the territory referred to in the Agreement by giving Cree and Inuit local government administrators jurisdiction over development decisions on Category I lands. These lands make up only a small proportion (approximately 1\%) of the lands in the area, however, and this level of control can have little impact on the protection of subsistence economies. Federal and provincial administrators are responsible for decisions about development in the remainder of the area referred to in the Agreement. While federal and provincial decision makers must consider recommendations from the review bodies established under the Agreement, these bodies (except for the KECQ) are nevertheless advisory in nature.

The KECQ's decision-making authority has been an important element contributing to its perceived effectiveness among northern EIA bodies (Jacobs and Kemp, 1987). The power allocated to the KECQ by its legislative base has meant that, although its evaluation process is applied in conjunction with the provincial Ministry of the Environment, it retains a semiautonomous role. Mulvihill and Keith (1989, 404-405) note that:
On one occasion, the commission suspended its approval of a regionally significant project (the relocation of a village) in which the Province was the proponent. Despite heavy pressure from the Ministry of Housing and the Ministry of the Environment, the KEQC was able to hold firm and withhold its approval until all of its conditions were met.

However, although most of these bodies lack jurisdiction over decisions about whether or not development should go forward, the requirement for social impact assessment may increase somewhat their level of political influence. Researchers have argued that the process of social impact assessment can facilitate community empowerment despite the communities' lack of formal jurisdiction over development decisions (Corbett, 1986). The process can provide a bargaining tool, allowing communities to negotiate the terms of development and in this way manage to some extent its social and economic impacts. It can also help build local leadership and community decision-making capacity (see also Gagnon et al., 1993). At the same time, it is important to remember the costs, both social and economic, of these kinds of battles. These costs have disproportionately been borne by the Native peoples.

\section{Incorporation of Cree and Inuit Values in Defining Effects of Development}

From her study of the Haida's participation in the Joint Canada/British Columbia West Coast Offshore Exploration Panel in 1984 and 1985, Shapcott (1989:68) highlighted the ethnocentric nature of environmental impact assessments in Canada:

Neither the courts nor the British Columbia Environmental Appeal Board can factor the social values of another culture into their decision-making. The values of the dominant culture are so imbedded in the process of EI (including that administered by the Environmental Assessment Review Process at the federal level), that alternative values cannot even be considered. As noted earlier, the underlying valuesboth the culture and the process-must be changed to making environmental impact assessment meaningful to Native people.

In part, culturally specific values enter into the assessment process through an identification of the aspects of the environment that need to be considered in the evaluation process. Beanlands and Duinker (1983:92) point out:

It is impossible for an impact assessment to address all potential environmental effects of a project. Therefore it is necessary that the environmental attributes considered to be important in project decisions be identified at the beginning of an assessment. 
Clearly, different cultures might vary widely in what are referred to as Valued Ecosystem Components or VECs.

Neither provincial nor federal impact assessment processes address the issue of VECs. There is nothing in sections 22 and 23 of the Agreement that requires that Cree and Inuit evaluations of aspects of the environment be employed in impact assessment. However the 1992 Guidelines set by the joint scoping and review committees asked Hydro-Quebec to describe the environment not only in light of existing written scientific knowledge, but also according to the precepts, values, and knowledge of the aboriginal people:

No description of the environment can ever be complete and exhaustive. Thus, it is preferable to carry out a systematic description focused primarily on valued ecosystem components....[T] he description of the different environments to be carried out by Hydro-Quebec shall take into account the knowledge of, and attitudes toward, the environment specific to the Cree and Inuit cultures. (Great Whale Public Review Support Office 1992:2, emphasis in the original)

In their joint evaluation of Hydro-Quebec's impact assessment of the project, the scoping and review committees found that the study's incorporation of Cree and Inuit values was inadequate (Provincial Review Committee et al., 1994). The Committees noted that the assessment was based on limited and outdated knowledge of the societies and cultures of the Native peoples in the territory referred to in the Agreement, and that information about the environmental knowledge and values of local communities was entirely absent. The Cree and Inuit have noted the general paucity of data to measure and monitor the effects of development projects (Brooke, 1995; Penn, 1995; Wilkinson and Vincelli, 1995). At present, the lack of data makes it difficult to demonstrate that subsistence harvests or tenure systems are being adversely affected. Wilkinson and Vincelli (1995) argue that Hydro-Quebec, as proponent of the major hydroelectric projects in the area, has principal responsibility for ensuring baseline data required for environmental assessment are collected systematically, and that this responsibility has not been exercised adequately.

Quebec's cancellation of the Great Whale project means that we do not know exactly how the requirement to incorporate Cree and Inuit values concerning the ecosystem would have been implemented in the final impact assessment. The existence of these provisions in the scoping guidelines for the Great Whale project does not ensure that similar guidelines will be employed for subsequent impact assessments of industrial development in the territory referred to in the Agreement. However scoping is a difficult exercise. It is likely, therefore, that future scoping committees will refer to these Guidelines, and they may provide a standard against which future exercises will be measured. As such, they can serve as an important precedent for incorporating Cree and Inuit values into the assessment process. Without information available about these components, however, the requirement to include them in an impact assessment may be a meaningless gesture.

\section{Incorporation of Cree and Inuit Values in Decision- making Processes}

Cree and Inuit values can be incorporated in decisionmaking processes through representation on various review bodies and through provisions for public participation. While Cree and Inuit representatives are not excluded from review bodies in federal and provincial impact assessment procedures, neither is their presence mandated.

Under the Agreement, Cree and Inuit representatives must be represented in the bodies that set guidelines for and evaluate impact assessments. Discovering the extent to which this participation creates a meaningful conduit for Cree and Inuit interests requires attention to more than the text of the Agreement, however. The dependence of the environmental regime on advisory committees with $\mathrm{Na}$ tive representation reflects the assumption of the Native negotiators that the interests of a small and economically marginal population could influence public policy through the creation of an interface with government representatives (Brooke, 1995; Penn, 1995). Experience with the review committees suggests that the significance of $\mathrm{Na}$ tive participation has been undermined by a number of factors during the tenure of the Agreement. These factors include the appointment to these committees of low-level civil servants, who have little authority for decision making; the frequent turnover of government representatives, which limits their ability to develop expertise on issues or real familiarity with Cree or Inuit cultures; and the unavailability of an independent research staff or research budget (Voinson, 1988; Brooke, 1995; Penn, 1995; Wilkinson and Vincelli, 1995). Wilkinson and Vincelli's (1995) review of the operation of these review bodies points out that Cree and Inuit representatives have been absent from more meetings than government representatives, and also that they have occasionally abstained from voting. The interpretation of these patterns is not entirely clear, and they may have much to do with issues of cultural appropriateness.

There are many indications that the processes of communication and decision making created by the Agreement are less than appropriate for Cree and Inuit cultures. Penn (1995) notes that Cree representatives to review bodies are often empowered to express collective viewpoints with respect to certain issues, but they are not empowered to negotiate or bargain without going back to their constituencies (see also Brooke, 1995). Wilkinson and Vincelli (1995) note that Cree and Inuit cultures are based on the oral transmission of knowledge and concerns and on decision making by consensus of locally or directly affected persons. Yet the environmental impact assessment regimes in the Agreement make fewer provisions for public 
participation than either existing federal or provincial regimes, and no provision was made in the Agreement for intervenor funding. Many of the reviews take place in southern locations. In addition, reviews rely heavily on written materials: the vast majority of these are in French or English, and many employ highly technical language. Brooke (1995) indicates that Inuit participants' expectation that their intimate knowledge of the land and wildlife would make a valuable contribution to the workings of the review bodies was not borne out. There has been little incorporation of traditional environmental knowledge in the deliberations of the committees to date (Brooke, 1995; Wilkinson and Vincelli, 1995). The result has been the increasing representation of the Cree and Inuit by younger people (who are not necessarily the most knowledgeable about or dependent on the environment) and heavy dependence on non-Native consultants. Wilkinson and Vincelli (1995) conclude that, although the review processes were expected to work differently in the area referred to in the Agreement because of attempts to incorporate Cree and Inuit values and participation, in fact they have not met those expectations.

\section{Incorporation of Cree and Inuit Values in Defining Desirable Futures}

Beyond assessing VECs from Cree and Inuit perspectives and ensuring Native participation in decision-making processes, some more general issues must be considered. These issues have to do with how economic development itself is evaluated. Tester (1992) has noted that environmental impact assessment processes in Canada have emphasized mitigative measures, and cases of developments cancelled as a result of social or environmental assessments have been very rare. Underlying these results are the assumptions that industrial development is positive, and that negative spin-offs are secondary results, which can be addressed through compensation or measures designed to minimize their impacts. Impact assessment processes provide virtually no consideration of broader values, for example, questioning the equation of development and progress or the inevitability of modernization, and considering alternative relationships between people and environments. Indigenous peoples' attempts to preserve subsistence economies often reflect an assessment of the desirability of industrial development very different from that of the developers.

Neither federal nor provincial legislation provides scope for evaluating existing practices or frameworks for managing industrial development. However, the James Bay Advisory Committee on the Environment (JBACE) and the Kativik Environmental Advisory Committee (KEAC) created under the Agreement have as part of their mandate the responsibility to evaluate legislation, policies, and regulations in the context of the principles laid out in sections 22 and 23. Unlike environmental impact assessment processes, which can only respond to proposals to change the status quo, these committees have the authority to evaluate current practices, including environmental assessment regimes, and to do so under their own initiative.

At the same time, these Committees are merely advisory to governments. Despite their status as the "preferential and official forum" for environmental protection measures in the territory referred to in the Agreement, they have not been given a clear role in government decisionmaking structures, which infrequently consult with them (Wilkinson and Vincelli, 1995). Moreover the ability of the Committees to undertake analysis of existing practices depends to a large extent on the degree to which these bodies are supported and consulted by federal and provincial governments. The Cree and Inuit have noted the general paucity of data available for measuring and monitoring the effects of development projects (Brooke, 1995; Penn, 1995; Wilkinson and Vincelli, 1995). The Cree have argued that federal and provincial governments have lacked a commitment to fully implement these Committees. As a result, they have not operated continuously or effectively; technical and scientific information, advice, and assistance have not been forthcoming; and an adequate secretariat has not been provided (Grand Council, 1987, 1991; Mainville, 1991; Penn, 1995; Wilkinson and Vincelli, 1995).

Apart from issues of implementation, there are also issues having to do with the relationship between rights to develop and rights to protect subsistence economies in the Agreement. The right to develop is one of the principles governing the operation of the environmental regime. All of the principles address the effects on Native economies of development. In other words, there seems to be an assumption that development is inevitable and desirable, and that the purpose of the principles enunciated in the Agreement is to minimize the negative effects of this development on Cree and Inuit hunting economies, rather than to halt development altogether.

At the same time, it is clear that the Agreement contemplates the possibility that the various review bodies may recommend that no development take place, and these recommendations could be made on the basis of negative effects on hunting economies. It is also clear that the Agreement gives the Cree and Inuit a number of rights, which include the protection of hunting economies and societies and the "guarantee of levels of harvesting equal to present levels of harvesting of all species in the Territory" (paragraph 24.6.2). It is not easy to ascertain which of these rights should take precedence in any particular situation. For example, paragraph 5.5.1 states that:

the rights and guarantees given to the Native people by and in accordance with the Section on Hunting, Fishing and Trapping shall be subject to the rights to develop Category III and Category II lands on the part of Quebec....However, the developers shall be submitted to the Environmental Regime which takes into account the Hunting, Fishing and Trapping Regime. (Canada, Quebec, 1976:70) 
The Agreement, then, appears to present mixed opportunities for affecting the direction of development in the territory referred to in the Agreement. While it seems to assume that industrial development will occur, with attempts to mitigate its effects, it also provides some avenues for the consideration of alternative futures. At some degree and scale of industrial development, it is clearly not possible to reconcile the protection of Cree and Inuit subsistence economies and the right to develop written into the agreement. To date, it seems that development initiatives have won out, particularly on Cree lands (Penn, 1995). But it is not clear whether this is so because the Agreement has not been fully or appropriately implemented, or because the rights the Agreement gave the Cree and Inuit to protect subsistence economies are subordinate to the right to develop in the territory referred to in the Agreement. As a result, it is difficult to ascertain the extent to which the Agreement allows for critical consideration of whether economic development is desirable in the territory referred to in the Agreement.

\section{CONCLUSION}

At the signing of the James Bay and Northern Quebec Agreement, Cree and Inuit expectations were that the Agreement would give them the tools with which they could exercise meaningful influence over development in the territory referred to in the Agreement, in order to protect their subsistence economies. The Agreement has not met the expectations of the Native parties to the Agreement. Some of the events and situations causing this dissatisfaction result from the wording and contents of the Agreement: it was written before there was much Canadian experience with environmental assessment, and in this sense it represents a pioneering document. This status also means that the experience of other groups could not inform the construction of the Agreement. Many sections of the Agreement appear to be vague and difficult to translate into workable principles. The advisory committee structure and process has not been well suited to Cree and Inuit cultures. The right to develop is woven through all sections on environmental protection. Finally, committee structures are exceedingly complex, involving federal and provincial governments, with separate areas of jurisdiction, in addition to Native representatives. This complexity is exacerbated in situations such as the Great Whale Project, which overlaps Cree and Inuit territories. When, in addition, governments have to be drawn into participating through legal means, it may become difficult to generate the consensus necessary to create less cumbersome procedures (see Brooke, 1995).

However, it is also very clear that there are major issues concerning implementation of the provisions of the Agreement. This makes it very difficult to evaluate the effectiveness of specific provisions. In this context, perhaps the strongest lesson to be learned from the Agreement has to do with the necessity of detailed plans for implementation.

\section{ACKNOWLEDGEMENTS}

The author would like to thank three reviewers for their helpful comments on the first draft of this paper. The research was funded through a Social Sciences and Humanities Research Council collaborative research grant (grant number 412-97-0014). Any remaining errors of fact or interpretation remain, of course, my own.

\section{REFERENCES}

BARROW, C.J. 1997. Environmental and social impact assessment: An introduction. New York: Arnold.

BEANLANDS, G.E., and DUINKER, P.N. 1983. An ecological framework for environmental impact assessment in Canada. Ottawa: Federal Environmental Assessment Review Office.

BERGER, T.R. 1985. Village journey: The report of the Alaska Native Review Commission. New York: Hill and Wang.

BOURASSA, R. 1985. Power From the North. Scarborough, Ontario: Prentice-Hall Canada.

BRASCOUPÉ, S. 1993. Strengthening traditional economies and perspectives. In: Royal Commission on Aboriginal Peoples. Sharing the harvest: The road to self-reliance. Ottawa: Supply and Services Canada. 101-119.

BRODY, H. 1983. Maps and dreams: A journey into the lives and lands of the Beaver Indians of Northwest Canada. New York: Penguin Books.

BROOKE, L.F. 1995. The James Bay and Northern Quebec Agreement: Experiences of the Nunavik Inuit with wildlife management. Ottawa: Royal Commission on Aboriginal Peoples.

BURGER, J. 1987. Report from the frontier: The state of the world's indigenous peoples. London: Zed Books Ltd.

CANADA. CANADIAN ENVIRONMENTAL ASSESSMENT RESEARCH COUNCIL (CEARC). 1985. Social impact assessment: A research prospectus. Ottawa: CEARC Secretariat.

CANADA. FEDERAL ENVIRONMENTAL ASSESSMENT REVIEW OFFICE. 1986. Federal environmental assessment and review process: Initial assessment guide. Ottawa: Minister of Supply and Services.

CANADA, QUEBEC. 1976. The James Bay and Northern Quebec Agreement. Montreal: Editeur officiel du Québec.

CANADIAN WILDLIFE FEDERATION INC. V. CANADA (MINISTER OF THE ENVIRONMENT) [1989] 3 F.C. 309.

CIACCIA, THE HON. J. 1976. Opening remarks to the standing parliamentary committee of the National Assembly of Quebec convened to examine the Agreement with the James Bay Crees and the Inuit of Quebec prior to its signature, 5 November, 1975. In: The James Bay and Northern Quebec Agreement. Montreal: Editeur officiel du Québec. xi-xxiv.

CORBETT, R. 1986. A bargaining and community development approach to social impact assessment and management. Unpublished Master's thesis, Faculty of Environmental Design, The University of Calgary, Alberta, Canada.

CREE REGIONAL AUTHORITY V. ROBINSON [1991] 2 C.N.L.R. 41 (F.C.T.D.) March 13, 1991. 
CREE REGIONAL AUTHORITY V. ROBINSON [1991] 4 C.N.L.R. 84 (F.C.T.D.) September 10, 1991.

DAY, J.C., and QUINN, F. 1992. Water diversion and export: Learning from Canadian experience. Waterloo: Department of Geography, University of Waterloo.

ELIAS, P.D., and WEINSTEIN, M.S. 1992. Development and the Indian people of Fort Ware: Predicting and managing consequences. Unpublished study for the Kaska Dene Council and the Community of Fort Ware. Ottawa: Department of Indian Affairs and Northern Development Library.

EVALUATING COMMITTEE, KATIVIK ENVIRONMENTAL QUALITY COMMISSION, FEDERAL REVIEW COMMITTEE NORTH OF THE 55TH PARALLEL, FEDERAL ENVIRONMENTAL ASSESSMENT REVIEW PANEL. 1992.

Guidelines: Environmental impact statement for the proposed Great Whale River hydroelectric project. Montreal: Great Whale Public Review Support Office.

FEIT, H. 1980. Protecting indigenous hunters' ways of life: The social and environmental protection regime in the James Bay and Northern Quebec Aboriginal Rights Agreement. Unpublished paper presented at The Conference on Social Impacts of Natural Resource Development on Indigenous Peoples, Ithaca, New York, 19-20 August 1980.

- 1988. The power and the responsibility: Implementation of the wildlife and hunting provisions of the James Bay and Northern Quebec Agreement. In: Vincent, S., and Bowers, G., eds. The James Bay and Northern Quebec Agreement: Ten years after. Montreal: Recherches amérindiennes au Québec. 74-88.

- 1989. James Bay Cree self-governance and land management. In: Wilmsen, E.N., ed. We are here: Politics of aboriginal land tenure. Berkeley: University of California Press. 68-98.

FRIENDS OF THE OLDMAN RIVER SOCIETY v. CANADA (MINISTER OF TRANSPORT) [1992] 1 S.C.R. 3.

GAGNON, C., HIRSCH, P., and HOWITT, R. 1993. Can SIA empower communities? Environmental Impact Assessment Review 13:229-252.

GRAND COUNCIL OF THE CREES (OF QUEBEC). 1991. Submission to the Cree-Naskapi Commission Community Tour, March 9. Ottawa: Cree-Naskapi Commission.

GRAND COUNCIL OF THE CREES (OF QUEBEC) and THE CREE REGIONAL AUTHORITY. 1987. Annual Report. Montreal: Grand Council of the Crees (of Quebec) and the Cree Regional Authority.

- 1995. Annual Report. Montreal: Grand Council of the Crees (of Quebec) and the Cree Regional Authority.

GREAT WHALE PUBLIC REVIEW SUPPORT OFFICE. 1992.

Background information: Guidelines for the environmental impact statement for the proposed Great Whale River hydroelectric project. Montreal: Great Whale Public Review Support Office.

HODGINS, B.W., and CANNON, K.A. 1995. On the land: Confronting the challenges to aboriginal self-determination in northern Quebec and Labrador. Toronto: Betelgeuse Books.

HYDRO-QUEBEC v. A.-G. CANADA ET AL. [1991] 3 C.N.L.R. 41 (Quebec Court of Appeal) March 28, 1991.

JACOBS, P., and KEMP, W.B. 1987. New institutions and land-use planning in northern Quebec. In: Hinterland or homeland?
Land-use planning in northern Canada. Ottawa: Canadian Arctic Resources Committee.

JULL, P. 1988. Behind the headlines: Canada, Arctic peoples and international affairs. Toronto: Canadian Institute of International Affairs.

KAYAHNA TRIBAL AREA COUNCIL. 1985. The Kayahna Region land utilization and occupancy study. Toronto: University of Toronto Press.

LaRUSIC, I.E. 1979. Negotiating a way of life: Initial Cree experience with the administrative structures arising from the James Bay Agreement. Ottawa: Research Division, Policy, Research and Evaluation Group, Department of Indian Affairs and Northern Development.

MAINVILLE, R. 1991. The James Bay and Northern Quebec Agreement. Unpublished paper presented at The Canadian Institute of Resources Law Fifth Conference on Resources Law, May 9-11. Ottawa: The Canadian Institute of Resources Law. MULVIHILL, P.R., and KEITH, R.F. 1989. Institutional requirements for adaptive EIA: The Kativik Environmental Quality Commission. Environmental Impact Assessment Review 9:399-412.

NOTZKE, C. 1994. Aboriginal peoples and natural resources in Canada. North York: Captus University Publications.

NUTTALL, M. 1994. Greenland: Emergence of an Inuit homeland. In: Minority Rights Group, eds. Polar peoples: Self-determination and development. London: Minority Rights Publications. 1-28.

PENN, A. 1988. Comments. In: Vincent, S., and Bowers, G., eds. The James Bay and Northern Quebec Agreement: Ten years after. Montreal: Recherches amérindiennes au Québec. 127-131.

. 1995. The James Bay and Northern Quebec Agreement: Natural resources, public lands, and the implementation of a Native land claim settlement. Ottawa: Royal Commission on Aboriginal Peoples.

PETERS, E.J. 1989. Federal and provincial responsibilities for the James Bay Cree, Naskapi and Inuit under the James Bay and Northern Quebec Agreement and the Northeastern Quebec Agreement. In: Hawkes, D.C., ed. Aboriginal peoples and government responsibility: Exploring federal and provincial roles. Ottawa: Carleton University Press. 173-242.

POSLUNS, M. 1993. Voices from the Odeyak. Toronto: NC Press Limited.

PROVINCIAL REVIEW COMMITTEE (COMEX), ENVIRONMENTAL AND SOCIAL IMPACT REVIEW PANEL NORTH OF THE 55TH PARALLEL (COFEXNORTH), ENVIRONMENTAL AND SOCIAL IMPACT REVIEW PANEL SOUTH OF THE 55TH PARALLEL (COFEX-SOUTH), FEDERAL ENVIRONMENTAL ASSESSMENT REVIEW PANEL (FEARP) OF THE PROPOSED GREAT WHALE PROJECT, and KATIVIK ENVIRONMENTAL QUALITY COMMISSION (KEQC), 1994. Joint report on the conformity and quality of the environmental impact statement for the proposed Great Whale River hydroelectric project. Montreal: Great Whale Public Review Support Office.

REED, M.G. 1990. Environmental assessment and aboriginal claims: Implementation of the Inuvialuit Final Agreement. Ottawa: Canadian Environmental Assessment Research Council. 
RICHARDSON, B. 1975. Strangers devour the land. Toronto: Macmillan of Canada.

ROSS, H. 1990. Community social impact assessment: A framework for indigenous peoples. Environmental Impact Assessment Review 10:185-193.

SALISBURY, R.F. 1986. A homeland for the Cree: Regional development in James Bay 1971-1981. Kingston: McGillQueen's University Press.

SHAPCOTT, C. 1989. Environmental impact assessment and resource management, a Haida case study: Implications for Native people of the North. The Canadian Journal of Native Studies. 9(1):55-83.

SIMON, M. 1992. Environments, sustainable development and self-government. Etudes/Inuit/Studies 16(1-2):21-26.

STEA, D., and WISNER, B. 1984. Introduction. Antipode 16(2): $3-13$.

TESTER, F.J. 1992. Reflections on Tin Wis: Environmentalism and the evolution of citizen participation in Canada. Alternatives 19(1):34-41.
VOINSON, M. 1988. The agreement: A possible vehicle of emancipation or a strategy for subjection? In: Vincent, S., and Bowers, G., eds. The James Bay and Northern Quebec Agreement: Ten years after. Montreal: Recherches amérindiennes au Québec. 292-293.

WEINSTEIN, M. S., TANNER, A., USHER, P., and DENTON, D. 1992. Great Whale River Project. Environment review: Social impact panel. Unpublished testimony on behalf of the Grand Council of the Crees (of Quebec): Presentation of the Social Impacts Panel. Available at Department of Indian Affairs and Northern Development Library, Ottawa.

WILKINSON, P.F., and VINCELLI, M. 1995. The James Bay and Northern Quebec Agreement: An evaluation of the implementation of its environmental regimes. Ottawa: Royal Commission on Aboriginal Peoples.

YERGEAU, M. 1988. The boldness of the agreement in environmental matters. In: Vincent, S., and Bowers, G., eds. James Bay and Northern Quebec Agreement: Ten years after. Montreal: Recherches amérindiennes au Québec. 296.

YOUNG, E. 1995. Third World in the First: Development and indigenous Peoples. New York: Routledge. 